\section{Control of Height and Flowering of Ixia Hybrids as Container Plants}

\author{
George J. Wulster ${ }^{1}$ \\ Department of Plant Science, Rutgers University, P.O. Box 231, New Brunswick, \\ NJ 08903-0231
}

\author{
Thomas M. Ombrello \\ Biology Department, Union County College, Cranford, NJ 07016
}

Additional index words. growth regulator, growth retardant, triazole, paclobutrazol, preplant treatment

\begin{abstract}
Growth and flowering of Ixia hybrids as potted plants can be controlled environmentally by cool preplant storage of corms, regulation of greenhouse forcing temperatures, and application of a growth retardant. Paclobutrazol applied as a preplant corm soak, a postemergent drench, or a postemergent spray in combination with a 2- to 4-week preplant storage of corms at $7^{\circ} \mathrm{C}$, and an $18{ }^{\circ} \mathrm{C}$ day/10 ${ }^{\circ} \mathrm{C}$ night forcing temperature produced attractive and marketable plants. Chemical name used: $\beta$-[(4-chlorophenyl)methyl]- $\alpha$-(1,1-dimethylethyl)-1H-1,2,4-triazole-1-ethanol (paclobutrazol, Bonzi ${ }^{\circledR}$ ).
\end{abstract}

Ixia is a genus of $\approx 50$ species native to South Africa. Commonly known as cornflowers or corn lilies, they are winter-growing, summer-dormant perennials. Hybrids are grown as cut flowers in Europe, and as garden plants in warmer regions of the United States. [U.S. Dept. of Agriculture hardiness zones 8-10, 6-8 with protection]. Ixia corms produce lance-shaped leaves and a spike with star-shaped flowers (3-4 cm across) consisting of six tepals in a variety of colors. Pot production of Ixia in the United States is limited because plants grow tall $(60 \mathrm{~cm}+)$ and require staking or wire-framed supports to be held upright (DeHertogh and LeNard, 1993; Everett, 1982).

The performance of Freesia, a relative of Ixia in the family Iridaceae, is influenced by preplant storage temperatures, forcing temperatures, and plant growth regulator applications. Ancymidol [ $\alpha$-cyclopropyl- $\alpha$ (4-methoxyphenyl)-5-pyrimidinemethanol] and paclobutrazol reduced plant height and flower stalk length of Freesia, but did not affect the number of flowering spikes per pot or the number of days to flower (Gianfagna and Wulster, 1986). Preplant storage of corms at $5{ }^{\circ} \mathrm{C}$ reduced leaf and flower stalk length and hastened bloom. Combinations of plant growth regulator applications and cool preplant treatments of Freesia corms produced the greatest reductions in leaf and flower stalk length (Wulster and Gianfagna, 1991).

Received for publication 1 June 1999. Accepted for publication 24 Jan. 2000. Research funded by the New Jersey Agricultural Experiment Station. Hatch project number 12175 . We thank Pedro Perdomo for his assistance in the statistical analysis of the data. The cost of publishing this paper was defrayed in part by the payment of page charges. Under postal regulations, this paper therefore must be hereby marked advertisement solely to indicate this fact.

'Extension Specialist. E-mail address: Wulster@ aesop.rutgers.edu.
Preliminary work by the senior author suggested that Ixia responds to temperature and plant growth regulator applications in a manner similar to Freesia.

The objective of this study was to evaluate the suitability of Ixia as a container crop using chemical and environmental treatments similar to those that were successful in growmarket.

\section{Materials and Methods}

Two thousand corms (6 $\mathrm{cm}$ diameter) each of a red-flowering and a white-flowering Ixia hybrid (no cultivars stated) were ordered through The Langeveld Bulb Co., Freehold, N.J., in Sept. 1996. On 21 Nov. 1996, the corms were planted ( 5 per $810 \mathrm{~mL}$ pot) $2 \mathrm{~cm}$ deep in a growing medium consisting of $35 \%$ sphagnum peat, $35 \%$ vermiculite and $30 \%$ rockwool supplemented with $\left(\mathrm{kg} \cdot \mathrm{m}^{-3}\right): 4$ dolomitic limestone, $10 \mathrm{~N}-8.7 \mathrm{P}-0 \mathrm{~K}, 1.25 \mathrm{~N}-$ $4.4 \mathrm{P}-4.2 \mathrm{~K}, 0.03$ fritted trace elements (Peters, Fogelsville, Pa.), and 0.07 Aquagrow granular surfactant (Aquatrols, Pennsauken, N.J.). After emergence, the plants were fertigated once weekly, alternating $100 \mathrm{mg} \cdot \mathrm{L}^{-1}$ $\mathrm{N}$ as $20 \mathrm{~N}-4.3 \mathrm{P}-16.6 \mathrm{~K}$ with $100 \mathrm{mg} \cdot \mathrm{L}^{-1} \mathrm{~N}$ as $\mathrm{CaNO}_{3}(15.5 \mathrm{~N}-0 \mathrm{P}-0 \mathrm{~K})$.

Corms (500 of each cultivar) were placed at $7{ }^{\circ} \mathrm{C}$ in open trays $0,2,4$, and 6 weeks prior to 21 Nov., when all were removed and planted. The pots were held under a "cool" $\left(18^{\circ} \mathrm{C}\right.$ day $/ 10^{\circ} \mathrm{C}$ night $)$ or a "warm" $\left(22^{\circ} \mathrm{C}\right.$ day $/ 18^{\circ} \mathrm{C}$ night) temperature regime established in separate sections of a glasshouse. Temperature treatments were not replicated and consequently were treated as blocks in the statistical analysis. Paclobutrazol (all concentrations in a.i.) was applied in three different ways: soaking of corms; soil application following planting; and as a foliar spray. Corms were soaked overnight $(15 \mathrm{~h})$ in paclobutrazol solutions $\left(0,50\right.$, or $\left.100 \mathrm{mg} \cdot \mathrm{L}^{-1}\right)$ ing several Freesia cultivars for the container immediately prior to planting. Paclobutrazol was applied as a soil drench $(0.25$ or $0.50 \mathrm{mg}$ / pot) when plants where $3 \mathrm{~cm}$ tall, or sprayed twice $\left(100\right.$ or $\left.200 \mathrm{mg} \cdot \mathrm{L}^{-1}\right)$ on the plants when they were 8 and $20 \mathrm{~cm}$ in height. The four storage durations and seven growth regulator treatments were arranged factorially, giving 28 treatment combinations for each cultivar in each glasshouse, with seven pots per treatment.

The days from planting to anthesis were recorded for the first plant to bloom in each pot. After all the flowers in each pot had senesced, leaf and flower stalk length (from medium surface to tip) and the number of flowers in each pot were recorded. The SAS statistical procedure GLM (SAS Institute, Gary, Ind.) was used for analysis of variance of all variables because of missing data in some treatments. Means were separated by a Fischer's protected LSD at $P \leq 0.05$ when F values were significant.

\section{Results and Discussion}

Reduction of leaf and flower stalk lengths, and of number of days to anthesis was generally proportional to the number of days of exposure to the $7^{\circ} \mathrm{C}$ pretreatment (Table 1). The white Ixia hybrids produced fewer flowers than did the red hybrids, but the flower numbers of both hybrids were reduced to a similar degree by the longest pretreatment ( 6 weeks). Ixia responded to cool preplant storage treatments in a manner similar to Freesia (Wulster and Gianfagna, 1991).

Both red and white Ixia grown in the warmer greenhouse "block" had significantly longer leaves, fewer flowers, and greater number of days to anthesis. Warmer temperatures reduced flower stalk length of the red Ixia, but not the white (Table 1).

All six paclobutrazol treatments reduced leaf and flower stalk lengths of both the red and white Ixia (Table 1), but the $200 \mathrm{mg} \cdot \mathrm{L}^{-1}$ spray was the most effective. The leaf and flower stalk reductions were similar in magnitude to those of the $7{ }^{\circ} \mathrm{C}$ preplant storage treatments. No treatment interactions were significant for white Ixia; however, a significant interaction was observed between PGR treatment and storage time for the red cultivar for the variables leaf and flower stalk length (Table 1). The effects of spray treatments on height did not change with storage time, while drench and preplant soaks reduced height to a greater extent as storage time increased. We suggest that the reason for this was the reduction in length and consequently leaf area with increasing corm storage time. The leaf area to be sprayed became less; consequently, we were delivering less material in covering the foliage. The flower stalks were not accessible to direct spray, so the amount of material actually available to translocate to the stalk was also reduced. Although a similar pattern was observable for the white cultivar, it was statistically nonsignificant. This is consistent with the observation that the red cultivar in general was more responsive to the various treatments than the white. 
Table 1. Main effects of time of storage of corms, greenhouse temperature, and method of paclobutrazol treatment on growth and flowering of red and white Ixia

\begin{tabular}{|c|c|c|c|c|c|c|c|c|}
\hline \multirow{3}{*}{$\begin{array}{l}\text { Treatment } \\
\mathrm{cv} \text {. }\end{array}$} & \multicolumn{4}{|c|}{ Length $(\mathrm{cm})$} & \multirow{2}{*}{\multicolumn{2}{|c|}{$\begin{array}{l}\text { Flowers } \\
\text { per pot }\end{array}$}} & \multirow{2}{*}{\multicolumn{2}{|c|}{$\begin{array}{c}\text { Days } \\
\text { to anthesis }\end{array}$}} \\
\hline & \multicolumn{2}{|c|}{ Leaves } & \multicolumn{2}{|c|}{ Flower stalks } & & & & \\
\hline & $\overline{\text { Red }}$ & White & Red & White & Red & White & Red & White \\
\hline \multicolumn{9}{|c|}{ Storage of corms at $7{ }^{\circ} \mathrm{C}$ (weeks) } \\
\hline 0 & $41 \mathrm{a}^{2}$ & $50 \mathrm{a}$ & $49 \mathrm{a}$ & $64 \mathrm{a}$ & $96 \mathrm{~b}$ & $51 \mathrm{a}$ & $150 \mathrm{a}$ & 156 \\
\hline 2 & $41 \mathrm{a}$ & $50 \mathrm{a}$ & $46 \mathrm{~b}$ & $64 \mathrm{a}$ & $102 \mathrm{a}$ & $54 \mathrm{a}$ & $139 \mathrm{~b}$ & \\
\hline 4 & $40 \mathrm{~b}$ & $47 \mathrm{~b}$ & $43 \mathrm{c}$ & $57 \mathrm{~b}$ & $93 \mathrm{~b}$ & $55 \mathrm{a}$ & $126 \mathrm{c}$ & $120 \mathrm{~b}$ \\
\hline 6 & $36 \mathrm{c}$ & $42 \mathrm{c}$ & $38 \mathrm{~d}$ & $52 \mathrm{c}$ & $80 \mathrm{c}$ & $44 \mathrm{~b}$ & $101 \mathrm{~d}$ & $112 t$ \\
\hline \multicolumn{9}{|c|}{ Greenhouse temperature ${ }^{y}$} \\
\hline Cool & $37 \mathrm{a}$ & $42 \mathrm{a}$ & $47 \mathrm{a}$ & $58 \mathrm{a}$ & $112 \mathrm{a}$ & $58 \mathrm{a}$ & $123 \mathrm{a}$ & 126 \\
\hline Warm & $43 \mathrm{~b}$ & $52 \mathrm{~b}$ & $41 \mathrm{~b}$ & $60 \mathrm{a}$ & $73 \mathrm{~b}$ & $44 \mathrm{~b}$ & $134 \mathrm{~b}$ & 141 \\
\hline \multicolumn{9}{|c|}{ Paclobutrazol treatment } \\
\hline 0 & $54 \mathrm{a}$ & $64 \mathrm{a}$ & $85 \mathrm{a}$ & $94 \mathrm{a}$ & $103 \mathrm{a}$ & $54 \mathrm{a}-\mathrm{c}$ & $122 \mathrm{~d}$ & 124 \\
\hline \multicolumn{9}{|c|}{ Corm soak $\left(m g \cdot L^{-1}\right)$} \\
\hline 50 & $40 \mathrm{c}$ & $47 \mathrm{c}$ & $41 \mathrm{c}$ & $59 \mathrm{c}$ & $96 \mathrm{bc}$ & $49 \mathrm{~cd}$ & $133 \mathrm{~b}$ & 135 \\
\hline 100 & $35 \mathrm{e}$ & $42 \mathrm{e}$ & $34 \mathrm{~d}$ & $50 \mathrm{e}$ & $76 \mathrm{e}$ & $42 \mathrm{e}$ & $137 \mathrm{a}$ & 141 \\
\hline \multicolumn{9}{|c|}{ Drench (mg/pot) } \\
\hline 0.25 & $43 \mathrm{~b}$ & $51 \mathrm{~b}$ & $51 \mathrm{~b}$ & $68 \mathrm{~b}$ & $100 \mathrm{ab}$ & $57 \mathrm{a}$ & $124 \mathrm{~d}$ & 142 \\
\hline 0.5 & $38 \mathrm{~d}$ & $45 \mathrm{~d}$ & $40 \mathrm{c}$ & $55 \mathrm{~d}$ & $93 \mathrm{c}$ & $52 \mathrm{~b}-\mathrm{d}$ & $128 \mathrm{c}$ & 128 \\
\hline \multicolumn{9}{|c|}{ Plant spray $\left(m g \cdot L^{-1}\right)$} \\
\hline 100 & $36 \mathrm{e}$ & $44 \mathrm{de}$ & $33 \mathrm{~d}$ & $49 \mathrm{e}$ & $96 \mathrm{bc}$ & $55 \mathrm{ab}$ & $128 \mathrm{c}$ & 130 \\
\hline 200 & $31 \mathrm{f}$ & $37 \mathrm{f}$ & $24 \mathrm{e}$ & $38 \mathrm{f}$ & $85 \mathrm{~d}$ & $47 \mathrm{de}$ & $131 \mathrm{bc}$ & 135 \\
\hline \multicolumn{9}{|c|}{ Interactions } \\
\hline PGR $\times$ storage $^{x}$ & * & NS & * & NS & NS & NS & NS & NS \\
\hline
\end{tabular}

${ }^{2}$ Mean separation within factors and columns by Fischer's protected LSD, $P \leq 0.05$.

${ }^{y} \mathrm{Cool}=$ day $18^{\circ} \mathrm{C}$, night $10^{\circ} \mathrm{C}$, warm $=$ day $22^{\circ} \mathrm{C}$, night $18^{\circ} \mathrm{C}$. Insufficient space prevented the replication of greenhouse temperature treatments which where treated as blocks.

×PGR $\times$ storage was significant at $P \leq 0.05$.

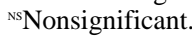

The number of flowers produced by the white Ixia was reduced by the preplant soak at $100 \mathrm{mg} \cdot \mathrm{L}^{-1}$ and by the spray at 200 $\mathrm{mg} \cdot \mathrm{L}^{-1}$. The red Ixia was more responsive to treatment, and only the $0.25-\mathrm{mg}$ drench did not reduce the number of flowers. Time to anthesis for white Ixia was unaffected by paclobutrazol treatment, but all treatments except the $0.25-\mathrm{mg}$ drench delayed anthesis for red Ixia (Table 1). The variability in days to anthesis was high for white Ixia, especially for those grown in the warmer greenhouse, resulting in statistically insignificant differences despite a wider range in flowering times. In addition, the first plants to bloom were consistently those that developed from corms subjected to the 6-week storage treatment and then grown in the warmer greenhouse without paclobutrazol. As observed for Freesia (Wulster and Gianfagna, 1991), the mechanism by which paclobutrazol reduces leaf and flower stalk elongation of Ixia may differ from that involved in preplant cooling, because paclobutrazol can delay anthesis, whereas preplant cooling hastens it.

Ixia hybrids can be grown as compact potted plants by manipulating the environment and employing a plant growth regulator. Several of the paclobutrazol treatments reduced leaf and flower stalk lengths without reducing flower number or delaying anthesis. Paclobutrazol in combination with a 2-4 week preplant cool storage, and cool growing temperatures in the greenhouse, produce a marketable plant. Greenhouse production of Ixia as a flowering container plant could be scheduled between more traditional fall and spring crops. The nonuniform responses of the two Ixia hybrids in this study, however, reflect basic differences that transcend flower color, and should be taken into consideration when growing members of this genus.

\section{Literature Cited}

DeHertogh, A. and M. LeNard. 1993. The physiology of flower bulbs. Elsevier Science, Amsterdam.

Everett, T.H. 1982. The New York Botanical Garden illustrated encyclopedia of horticulture. Garland Publishing, New York.

Gianfagna, T.J. and G.J. Wulster 1986. Growth retardants as an aid to adapting freesia to pot culture. HortScience 21:263-264.

Wulster, G.J. and T.J. Gianfagna. 1991. Freesia hybrida respond to ancymidol, cold storage of corms, and greenhouse temperatures. HortScience 26:1276-1278. 